\title{
Article \\ Thin Film Biocomposite Membrane for Forward Osmosis Supported by Eggshell Membrane
}

\author{
Teayeop Kim ${ }^{1,+}$, Sunho Park ${ }^{2,3,+}$, Yoonkyung Lee ${ }^{1} \mathbb{C}$, Jangho Kim ${ }^{2,3, *}$ and Kyunghoon Kim ${ }^{1, * \mathbb{C}}$ \\ 1 School of Mechanical Engineering, Sungkyunkwan University, Suwon 16419, Korea; skkty@skku.edu (T.K.); \\ yi9257kr@skku.edu (Y.L.) \\ 2 Department of Rural and Biosystems Engineering, Chonnam National University, Gwangju 61186, Korea; \\ preference9330@gmail.com \\ 3 BK21 FOUR Center for IT-Bio Convergence System Agriculture, Chonnam National University, \\ Gwangju 61186, Korea \\ * Correspondence: rain2000@jnu.ac.kr (J.K.); kenkim@skku.edu (K.K.) \\ + These authors contributed equally to this work.
}

check for updates

Citation: Kim, T.; Park, S.; Lee, Y.; Kim, J.; Kim, K. Thin Film

Biocomposite Membrane for Forward

Osmosis Supported by Eggshell

Membrane. Membranes 2022, 12, 166.

https://doi.org/membranes12020166

Academic Editors: Joseph Dumpler and Judy Lee

Received: 30 December 2021

Accepted: 25 January 2022

Published: 30 January 2022

Publisher's Note: MDPI stays neutral with regard to jurisdictional claims in published maps and institutional affiliations.

Copyright: (C) 2022 by the authors. Licensee MDPI, Basel, Switzerland. This article is an open access article distributed under the terms and conditions of the Creative Commons Attribution (CC BY) license (https:// creativecommons.org/licenses/by/ $4.0 /)$.

\begin{abstract}
There is a general drive to adopt highly porous and less tortuous supports for forward osmosis (FO) membranes to reduce internal concentration polarization (ICP), which regulates the osmotic water permeation. As an abundant waste material, eggshell membrane (ESM) has a highly porous and fibrous structure that meets the requirements for FO membrane substrates. In this study, a polyamide-based biocomposite FO membrane was fabricated by exploiting ESM as a membrane support. The polyamide layer was deposited by the interfacial polymerization technique and the composite membrane exhibited osmotically driven water flux. Further, biocomposite FO membranes were developed by surface coating with GO for stable formation of the polyamide layer. Finally, the osmotic water flux of the eggshell composite membrane with a low structural parameter $(\sim 138 \mu \mathrm{m})$ reached $46.19 \mathrm{~L} \mathrm{~m}^{-2} \mathrm{~h}^{-1}$ in FO mode using $2 \mathrm{M} \mathrm{NaCl}$ draw solution.
\end{abstract}

Keywords: forward osmosis; biomaterials; desalination; sustainable process

\section{Introduction}

Forward osmosis (FO), as a novel and emerging separation technique, has received attention for various applications from low-cost water purification [1] and renewable energy production [2] to protein enrichment [3]. Polyamide-based thin film composite (TFC) membranes are the most popularly used membrane type in FO [4]. TFC membranes have two important layers, a thin selective layer that enables osmotic water transport and a porous support layer that confers mechanical stability and enables molecule diffusion. In contrast with pressure driven separation, in the FO process, the transport property of the selective layer may be limited by internal concentration polarization (ICP) due to the support layer.

Higher water transport can be achieved in the FO process by enhancing the water permeability of the selective layer and by structural enhancement of the support layer to reduce the ICP. ICP reduces the effective osmotic pressure applied to the selective layer, as the permeated water dilutes the draw solution (DS) in the support layer.

The effective diffusion length through the support layer pore, which is defined as a structural parameter, affects the degree of ICP [5]. The low structural parameter results weaker ICP and can be achieved by higher porosity, thinner thickness, and lower pore tortuosity. To achieve a low value of the structural parameter corresponding to a lower ICP, a highly porous, thin, and less tortuous structure is needed. In previous studies on minimizing the ICP, structural parameter was reduced by optimizing the material composition [6,7] and incorporating nanoparticles [8-11] by the phase inversion method, and by employing a novel fabrication strategy using electrospinning [12-14]. The most effective results were 
achieved with a polymeric fibrous support fabricated by electrospinning that decreased the value of the structural parameter and the tortuosity to $66 \mu \mathrm{m}$ and 1.2, respectively [13].

Despite these developments, contradictory environmental problems remain to be considered. Synthetic polymer materials constituting the FO membrane for water treatment are known to cause water pollution during the synthesis process [15]. Furthermore, additional hazardous organic solvents are used in the manufacturing process for polymeric membranes [16]. Therefore, not only performance of membranes, the environmental issue of material and process should be considered. Compared to these artificially fabricated polymeric supports for FO membranes, the eggshell membrane (ESM) has the required properties. In terms of the structural aspects, the ESM is thin $(\sim 100 \mu \mathrm{m})$ [17] and comprises an entangled microfibrous structure that is most desirable for reducing the ICP [18]. Furthermore, the unique properties of the ESM, including the flexibility, thermal stability [19], chemical stability to organics [20], and hydrophilic surface [21] enable further functionalization of the ESM layer via thermal and chemical processes for advanced applications. Most importantly, the ESM is derived from affordable waste materials. More than $10^{12}$ eggs are consumed annually [22], and most of the by-products, including the ESM, are disposed [23]. Therefore, the use of ESM based platforms instead of synthetic polymers leads to the reduction of chemical waste and the development of high-value products by using waste agricultural by-products.

Given the advantages and suitability of the ESM as an FO membrane support, we herein fabricate an ESM-based FO membrane combined with a polyamide selective layer (Figure 1a). Further, an ESM composite with graphene oxide (GO) is developed to overcome the problems encountered in FO membrane fabrication (Figure 1b). The fabricated FO membranes based on ESM and ESM-GO are evaluated in terms of the osmotic water flux and reverse ion flux using $\mathrm{NaCl}$ DS of different concentrations.

(a)

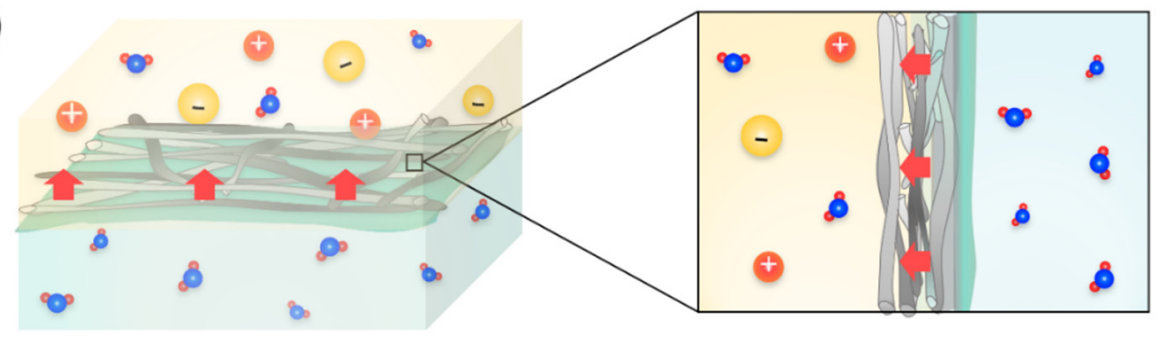

Polyamide deposited GO-ESM composite (ESC) membrane for forward osmosis

(b)
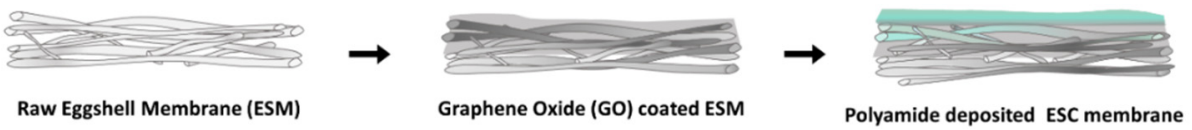

Figure 1. Schematic of (a) composite membrane for FO and (b) fabrication process.

\section{Materials and Methods}

\subsection{Materials}

Both 1,3,5-Benzenetricarbonyl trichloride (TMC, 98\%) and graphite power ( 200 mesh, 99.9\%) were purchased from Alfa-Aesar. m-Phenylenediamine (MPD, 99\%), and sodium nitrate $\left(\mathrm{NaNO}_{3}, 99 \%\right)$, and potassium permanganate $\left(\mathrm{KMnO}_{4}, 99 \%\right)$ were obtained from Sigma-Aldrich. Sodium chloride $(\mathrm{NaCl}, 99 \%)$, hydrogen peroxide $\left(\mathrm{H}_{2} \mathrm{O}_{2}, 30 \%\right)$, sulfuric acid $\left(\mathrm{H}_{2} \mathrm{SO}_{4}, 95 \%\right)$, and hydrochloric acid $(\mathrm{HCl}, 99 \%)$ were purchased from Daejung chemicals. Deionized water was produced by EXL-3 water purification system (Vivagen, Seongnam, Korea). 


\subsection{Preparation and Characterization of ESM and ESM-GO Composite}

ESM was manually separated from eggshells, and the prepared ESM was washed with DI water several times to remove the yolk and residue (Figure 2a). The separated ESM was cut into 20-mm rounds to control the shape of the sample, and the ESM was placed on a glass substrate.

(a)

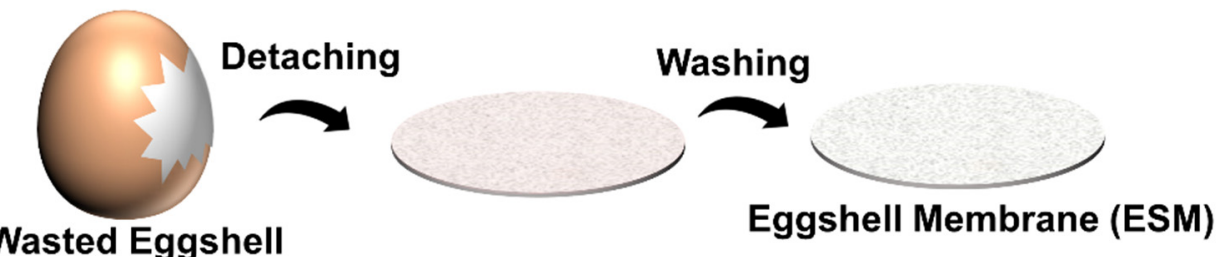

(b) Drop Casting of GO Solution

Spin Coating
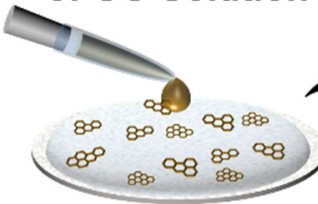

\section{(c) Interfacial Polymerization}
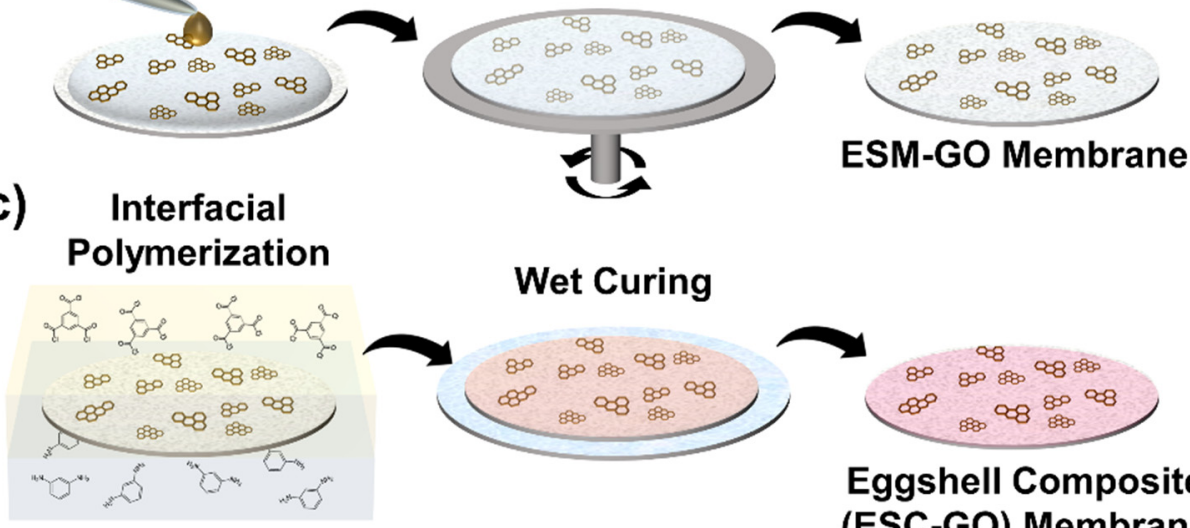

ESM-GO Membrane

Figure 2. Schematic of biocomposite membrane fabrication process: (a) ESM preparation, (b) GO coating and ESM-GO membrane, (c) active layer fabrication and ESC-GO membrane.

To obtain the flat and hydrophilic surface desired for polyamide layer deposition, one side of the prepared ESM was coated with graphene oxide. Graphene oxide was prepared by the modified Hummers method [24]. Briefly, $5 \mathrm{~g}$ of graphite and $2.5 \mathrm{~g}$ of sodium nitrate were combined with $115 \mathrm{~mL}$ of sulfuric acid under constant stirring in an ice bath. After $30 \mathrm{~min}, 15 \mathrm{~g}$ of $\mathrm{KMnO}_{4}$ was slowly added to the solution while maintaining the temperature below $20^{\circ} \mathrm{C}$. The mixture was stirred at $30{ }^{\circ} \mathrm{C}$ for $30 \mathrm{~min}$ and the resulting solution was diluted by adding $230 \mathrm{~mL}$ of hot water under vigorous stirring. The solution was further treated with $30 \% \mathrm{H}_{2} \mathrm{O}_{2}$ solution $(50 \mathrm{~mL})$ and $400 \mathrm{~mL}$ of water. The resulting mixture was washed with $\mathrm{HCl}$ and $\mathrm{H}_{2} \mathrm{O}$, respectively. To obtain a clear homogeneous solution, the prepared graphene was dispersed in DI water and sonicated for $2 \mathrm{~h}$ before use.

To obtain the flat and hydrophilic surface desired for polyamide layer deposition, one side of the prepared ESM was coated with graphene oxide. Graphene oxide was prepared by the modified Hummers method [24]. Briefly, $5 \mathrm{~g}$ of graphite and $2.5 \mathrm{~g}$ of sodium nitrate were combined with $115 \mathrm{~mL}$ of sulfuric acid under constant stirring in an ice bath. After $30 \mathrm{~min}, 15 \mathrm{~g}$ of $\mathrm{KMnO}_{4}$ was slowly added to the solution while maintaining the temperature below $20^{\circ} \mathrm{C}$. The mixture was stirred at $30{ }^{\circ} \mathrm{C}$ for $30 \mathrm{~min}$ and the resulting solution was diluted by adding $230 \mathrm{~mL}$ of hot water under vigorous stirring. The solution was further treated with $30 \% \mathrm{H}_{2} \mathrm{O}_{2}$ solution $(50 \mathrm{~mL})$ and $400 \mathrm{~mL}$ of water. The resulting mixture was washed with $\mathrm{HCl}$ and $\mathrm{H}_{2} \mathrm{O}$, respectively. To obtain a clear homogeneous solution, the prepared graphene was dispersed in DI water and sonicated for $2 \mathrm{~h}$ before use.

As illustrated in Figure 2b, GO solution $(0.1,0.5$, and $1 \% ; 140 \mu \mathrm{L})$ was uniformly coated on the ESM-glass substrate using a spin-coater (ACE-200) at $7000 \mathrm{rpm}$ for $30 \mathrm{~s}$ and dried at 
room temperature. Finally, fabricated ESM-GO composites were denoted by ESM-GO 0.1, $0.5,1$ following GO contents $(1,0.5,1 \%)$ of solution used in spin coating.

The morphology of the membranes and FO composite membranes was evaluated by field-emission scanning electron microscopy (FESEM, JEOL JSM-7600F). To prepare samples for cross-surface imaging, the membranes were fractured after freezing in liquid nitrogen. The Raman spectra of the membrane surface were acquired using a confocal Raman spectrometer (XperRam Compact, Nanobase, Seoul, Korea). The contact angle (CA) was analyzed with a contact angle analyzer (SDL200TEZD, FEMTOFAB Co., Ltd., Pohang, Korea) by dropping $3 \mu \mathrm{L}$ of DI water on the sample surface. The pure water permeability was calculated by measuring filtered deionized water through membranes for $10 \mathrm{~min}$, in vacuum filter applied $93 \mathrm{kPa}$.

\subsection{Deposition of Polyamide Layer}

A polyamide layer was prepared by interfacial polymerization on the membranes as illustrated in Figure 2c. MPD (2 wt \%) was dissolved in DI water and $0.1 \mathrm{wt} \%$ TMC was dissolved in $\mathrm{n}$-hexane by bath sonication for $1 \mathrm{~h}$. The prepared ESM or GO-ESM composite was immersed in DI water and placed in a desiccator for $1 \mathrm{~h}$ to wet the membrane and remove any microbubbles in the membranes. The wet membranes were placed in aqueous MPD solution for $5 \mathrm{~min}$ and placed on a flat glass plate. Thereafter, the aqueous MPD solution was removed by blowing with air and TMC-hexane solution was passed over the membrane surface for $90 \mathrm{~s}$. The membranes were instantly washed with pure n-hexane to remove non-reacted TMC and cured in a drying oven at $60^{\circ} \mathrm{C}$ for $5 \mathrm{~min}$ for stabilization [25] and to enhance interfacial adhesion between polyamide and the substrates. Finally, the fabricated ESM-based FO membranes were placed in DI water in the dark for $24 \mathrm{~h}$ to extract MPD from the membranes. The fabricated FO membranes are denoted as eggshell composite (ESC, ESC-GO 0.1 to 1) depending on the use of ESM or the ESM-GO composite membrane (ESM, ESM-GO 0.1 to 1 ).

\subsection{Lab-Scale FO Test}

The FO performance was evaluated by lab-scale FO tester presented in Figure 3. The FO performance, the prepared FO composite membrane was tightly held between rubbery O-rings with a diameter of $14 \mathrm{~mm}$. The DS was passed over the support layer, and the feed solution (FS) was passed over the polyamide layer with a constant flux of $250 \mathrm{~mL} \mathrm{~min}^{-1}$. DI water was used for $\mathrm{FS}$ and $\mathrm{NaCl}$ aqueous solution with different concentrations $(0.5,1,1.5$, and $2 \mathrm{M})$ used for DS. Each FO experiment was conducted for $2 \mathrm{~h}$ with each different sample.

The pure water flux $\left(J_{w}\right)$ was characterized based on the volume permeation per unit effective area and the experimental time according to the following equation:

$$
J_{w}=\frac{\Delta V_{f}}{A_{m} \cdot \Delta t}
$$

where, $\Delta V_{f}$ is the volume permeation of FS, $A_{m}$ is the active surface area of the membrane $\left(1.56 \mathrm{~cm}^{2}\right)$, and $\Delta t$ is the operation time for the experiment.

$$
J_{s}=\frac{\Delta\left(c_{f} V_{f}\right)}{A_{m} \cdot \Delta t}
$$

Here, $c_{f}$ and $V_{f}$ are the concentration and volume of $\mathrm{NaCl}$ in the FS, measured before and after the experiment.

The performance parameter of the membranes, pure water permeability $(A)$, ion permeability $(B)$, and structural parameter $(S)$ and coefficient of determination $\left(R^{2}\right)$ were 
determined using a analytical method developed by Alberto Tiraferri et al. [26] according to the equation:

$$
S=\frac{D}{J_{v}} \ln \frac{A \cdot \pi_{\text {draw }}+B}{A \cdot \pi_{\text {feed }}+J_{v}+B}
$$

where $\pi_{\text {draw }}$ and $\pi_{\text {feed }}$ are the osmotic pressure of the DS and FS calculated using the van't Hoff equation. $D$ is the diffusion coefficient of $\mathrm{NaCl}$ in aqueous solution, which was calculated in a previous study [27].

\section{(a)}

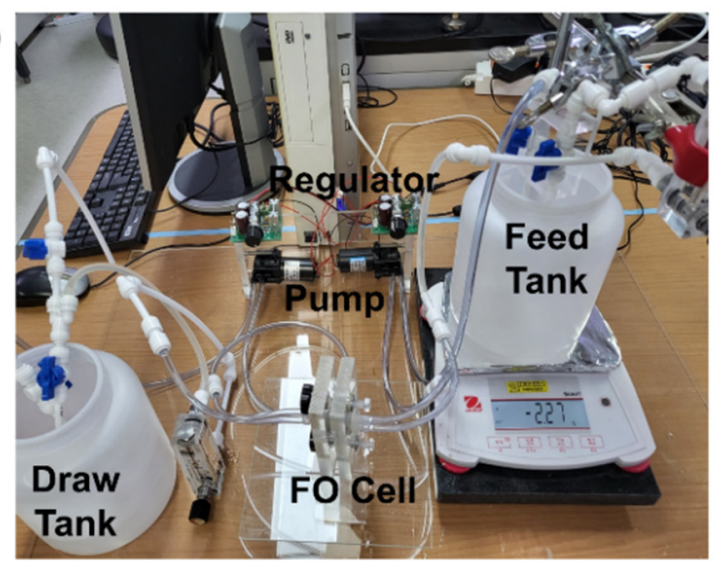

(b)

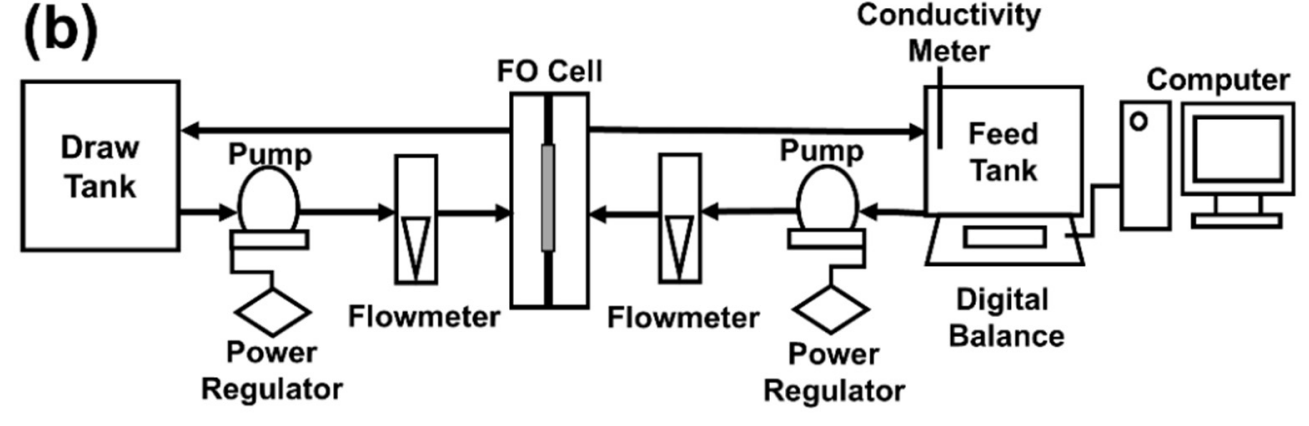

Figure 3. (a) Photograph and (b) schematic diagram of lab-scale FO experimental setup.

\section{Results and Discussion}

\subsection{Membrane Characterization}

Figure 4 shows the morphology of the cross-surface and top surface of the ESM and ESM-GO membranes imaged by FESEM. Before deposition of GO, the structure of the cross-surface (Figure 4a) and top surface (Figure 4e) was porous, composed of accumulated eggshell fibers randomly oriented. After the GO coating process, the GO flakes gradually cover the ESM surface in proportion to the loading. As GO loading increases, GO flakes partially cover the ESM-GO 0.1, 0.5 (Figure 4f,g) surface and fully cover the ESM-GO 1 (Figure $4 d, h$ ). As shown in Figure $4 b-d$, GO formed a thin layer on the surface of the ESM rather than infiltrating into the eggshell fibers. Compared to the surface of the bare ESM membrane, the surface of the ESM-GO membrane was flattened by GO that accumulated in the aperture between the eggshell fibers.

The pure water permeability was evaluated to investigate the effects of the deposited GO layer on the composite membrane (Figure 5a). The pure water permeability of ESM was as high as $15,400 \mathrm{~L} \mathrm{~m}^{-2} \mathrm{~h}^{-1}$ bar $^{-1}$, which is considerably higher than that of TFC membrane supports fabricated by phase inversion [8]. This high pure water permeability may be attributed to micro-scale flow paths between the eggshell fibers. After GO deposition, the pure water permeability gradually decreased for ESM-GO 0.1 and 0.5, but decreased dramatically for the ESM-GO 1 membrane. As shown in Figure $4 \mathrm{~h}$, the compact coverage of the GO layer over the entire surface of ESM-GO 1 caused a dramatic decline in the pure water permeability. 


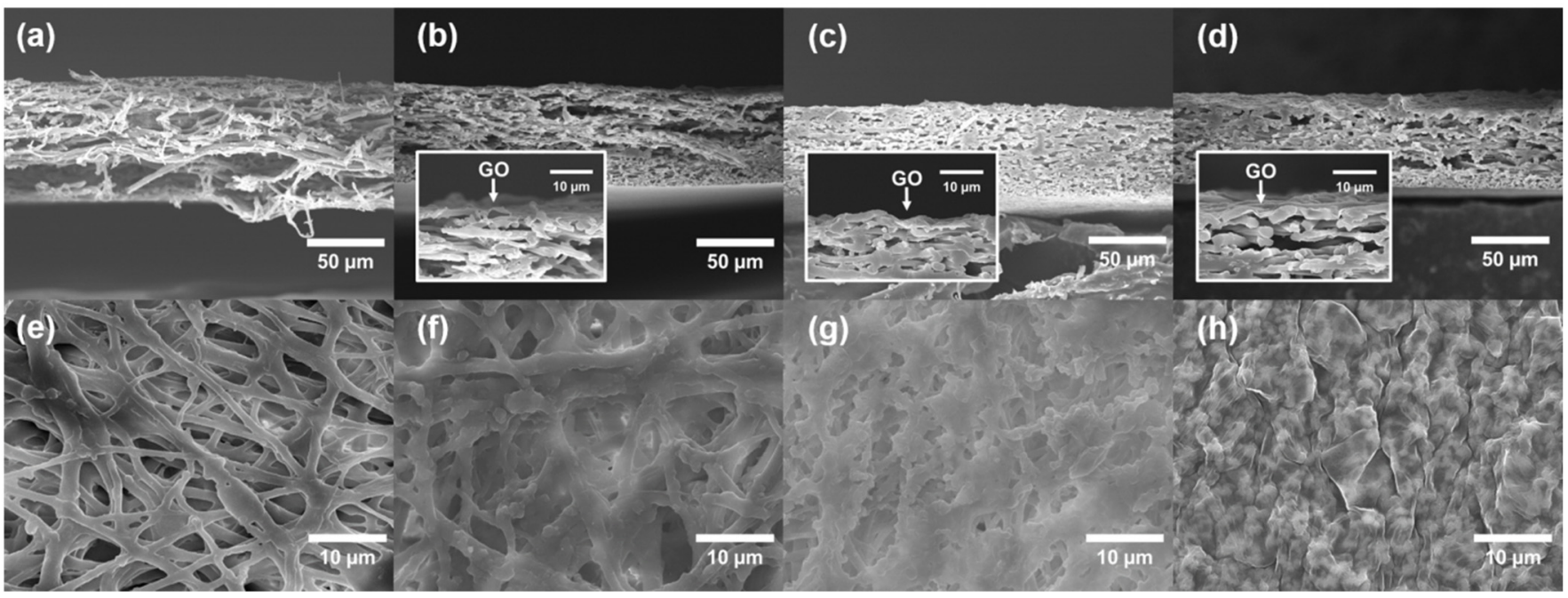

Figure 4. FESEM image of (a-d) top and (e-h) cross-surface of ESM (a,e) and ESM-GO composite membranes: ESM-GO 0.1 (b,f), ESM-GO $0.5(\mathbf{c}, \mathbf{g})$, and ESM-GO 1 (d,h).

(a)

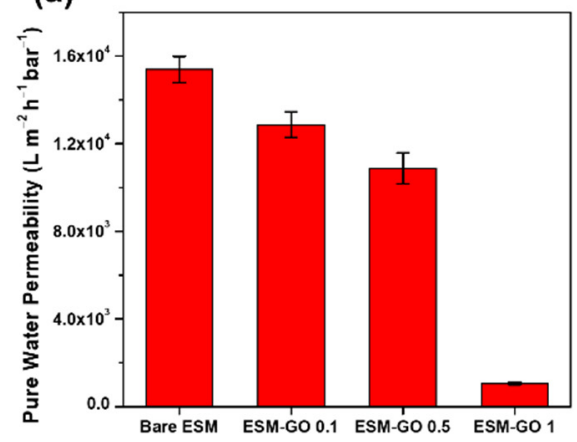

(b)

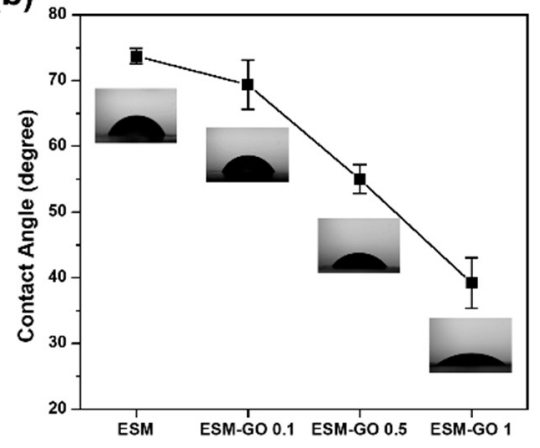

(c)

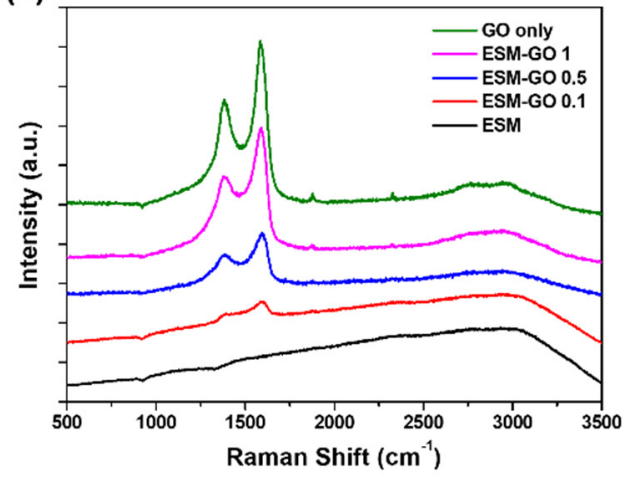

Figure 5. (a) Pure water permeability, (b) contact angle, and (c) Raman spectra of top surface of membrane.

The contact angles of the ESM and ESM-GO composites were measured to investigate the hydrophilicity, as shown in Figure 5b. In synthesis of polyamide-based desalination membrane, the hydrophilicity of the supporting layer contributed to enhanced interfacial adhesion with the polyamide layer [28-30]. Even before GO coating, the surface of the ESM was hydrophilic, as indicated by the contact angle of $74^{\circ}$, due to the numerous hydroxyl, carboxyl, and amide groups [21]. Nevertheless, the surfaces of the GO-coated ESM composite membranes (ESM-GO 0.1, 0.5, 1) were even more hydrophilic. The contact angle gradually decreased with increasing GO content and finally reached $\sim 39^{\circ}$ for ESMGO 1. These results suggest that more GO coated on the ESM enhanced the hydrophilicity of the ESM-GO composite membrane.

Figure $5 c$ shows the Raman spectra of bare GO and the top surface of the membrane, which were used to investigate the properties of GO and confirm deposition. In the Raman spectra of carbon materials, the G-band represents $\mathrm{sp}^{2}$ carbon atoms composing graphene and the D-band $\left(I_{d} / I_{g}=0.86\right)$ represents structural disorder, which is inevitable due to oxidation [31]. The Raman spectra $\left(I_{d} / I_{g}\right.$ ratio of 0.86$)$ confirm that GO is composed of oxidized graphene sheets [32]. The Raman spectrum of ESM did not present specific peaks. Therefore, the intensity of the D and G bands of the ESM-GO composite, which is proportional to the GO loading, indicates a deposited GO layer on the membrane surface. Consequently, the Raman spectra of ESM-GO 1 without the broad line induced by ESM indicate a considerably thickened GO layer that compactly covers the membrane surface. 


\subsection{Characterization of FO Membranes}

Figure 6 shows the intrinsic morphology of polyamide, described as a "ridge-andvalley" structure [33], which confirms deposition of the polyamide layer on the membrane surface. Compared to the bare ESC membrane (Figure 6a), the ridge-and-valley structure tended to become flatter as the GO content increased (Figure 6b-d). This tendency was observed in the GO/polyamide composite matrix and is attributed to hindrance of MPD diffusion by GO. After interfacial polymerization, the polyamide active layer was located on the eggshell fibers of the ESC membrane or GO layer of the ESC-GO membranes (Figure S1).

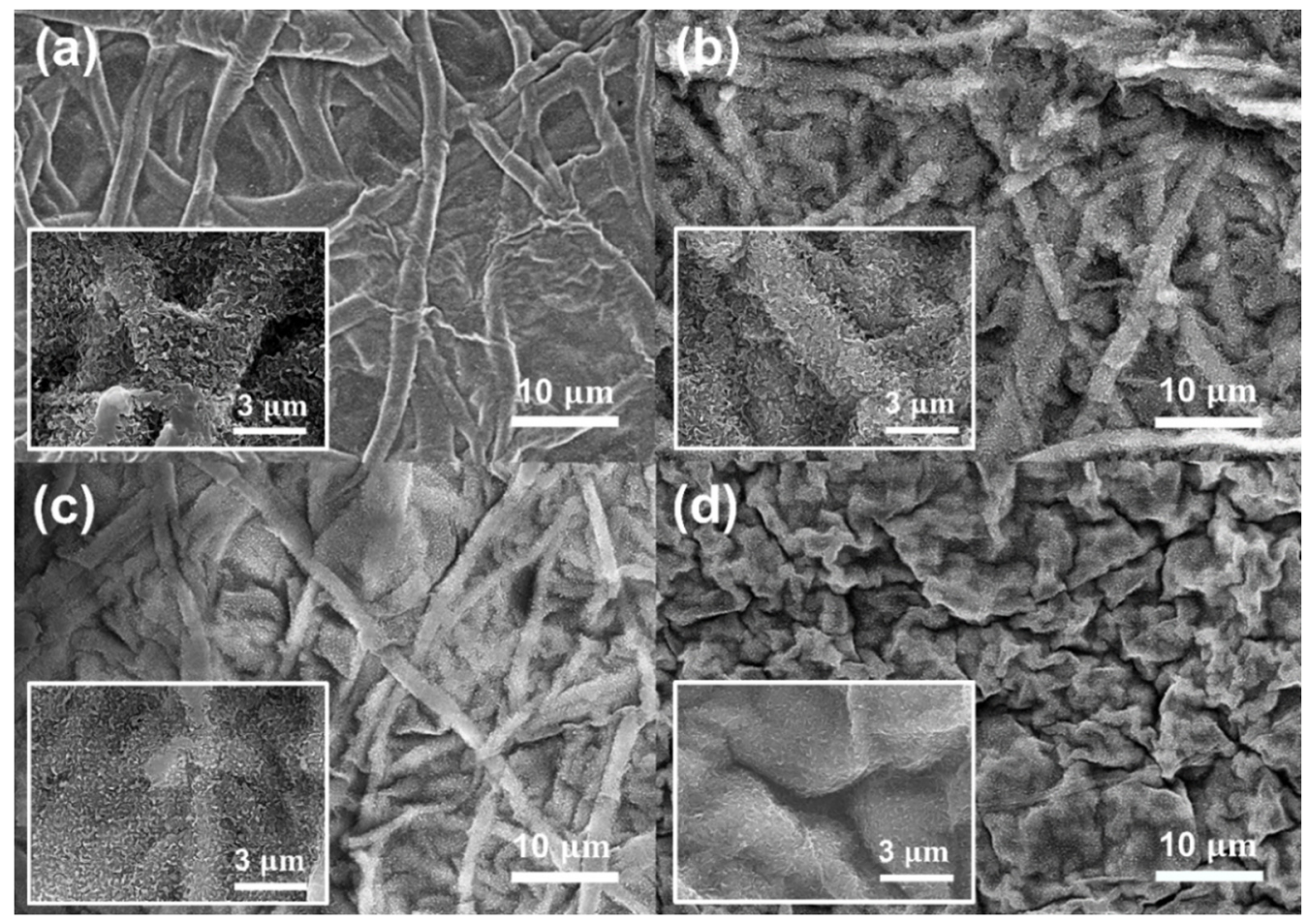

Figure 6. Morphology of FO membranes: (a) ESC, (b) ESC-GO 0.1, (c) ESC-GO 0.5, and (d) ESC-GO 1.

As shown in Figure 5, bare ESM has a relatively rough surface composed of protein fibers $(\sim 3 \mu \mathrm{m})$, compared to the electro-spun fibers $(\sim 150 \mathrm{~nm})$ used as the membrane support in previous studies [12,18]. This structural disadvantage led to some obvious defects in the polyamide layer, permitting direct ion transport (Figure S2). However, these hole-shaped defects were not found in ESC-GO 0.1 and 0.5 with the polyamide layer on the flattened surface (Figure $6 \mathrm{~b}, \mathrm{c})$. These results suggest that deposited GO enabled the stable formation of a thin polyamide layer due to the hydrophilic and flatter surface, whereas the morphology of ESC-GO 1 shows sharp wrinkles between the GO agglomerates (Figure 6d). The high content of GO in ESC-GO 1 formed a cracked surface consisting of GO agglomerates with an apparently large number of defects on the polyamide layer.

\subsection{Performance of ESC-FO Membrane}

As shown in Figure 7, the ESC membrane showed reasonable osmotic water flux (15.35 and $34.53 \mathrm{~L} \mathrm{~m}^{-2} \mathrm{~h}^{-1}$ in 0.5 and $2 \mathrm{M} \mathrm{NaCl}$ DS) and high reverse ion flux (4.34 and $0.05 \mathrm{~mol} \mathrm{~m}^{-2} \mathrm{~h}^{-1}$ in 0.5 and $2 \mathrm{M} \mathrm{NaCl}$ DS) in proportion to the $\mathrm{NaCl}$ concentration of DS. At high ion flux, the ESC membrane is less effective than the FO membranes based on polyamide [7] and cellulose acetate/triacetate (CA/CTA) [34,35]. However, compared to the bare ESC membrane, the reverse ion flux is $\sim 4$ times lower and the pure water flux is considerably enhanced for the ESC-GO 0.1 and 0.5 membranes. The water flux was highest $\left(19.2,46.19 \mathrm{~L} \mathrm{~m}^{-2} \mathrm{~h}^{-1}\right.$ in $0.5,2 \mathrm{M} \mathrm{NaCl}$ DS) and the reverse ion flux $\left(1.04,2.01 \mathrm{~mol} \mathrm{~m}^{-2} \mathrm{~h}^{-1}\right.$ in $0.5,2 \mathrm{M} \mathrm{NaCl} \mathrm{DS}$ ) was lowest for the ESC-GO 0.5 membrane. In contrast, the lowest 
water flux and highest reverse ion flux were obtained with ESC-GO 1. These results indicate that the ESC-GO 1 membrane does not reject ions effectively.
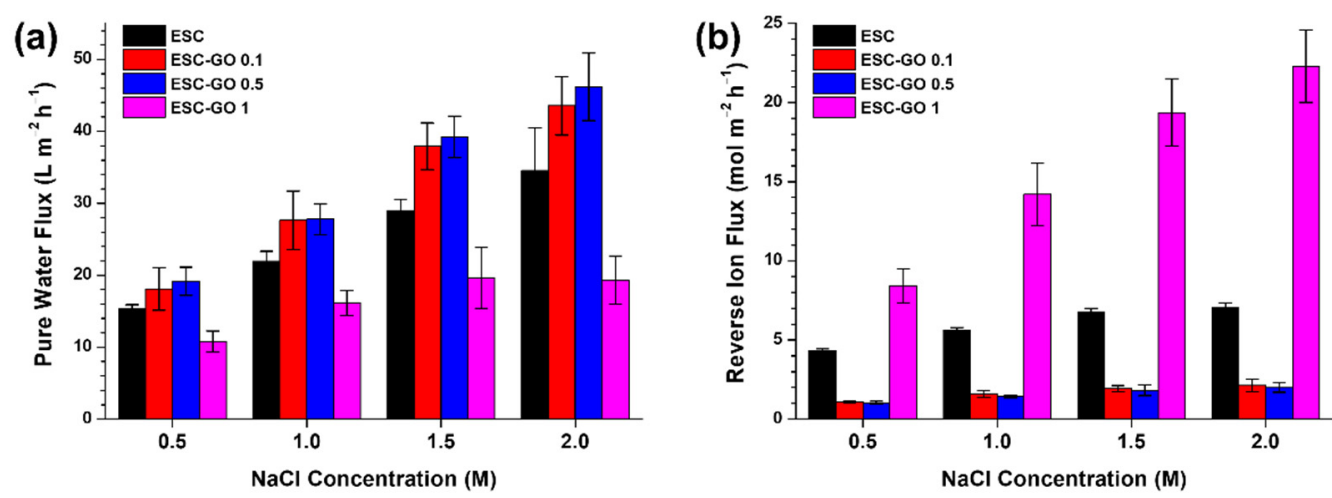

Figure 7. (a) Pure water flux and (b) reverse ion flux of FO membranes.

Before GO coating, as shown in Figure 5, the diameter of the protein fibers in the ESM was $0.3-2 \mu \mathrm{m}$ [36] with a wide aperture $(\sim 4 \mu \mathrm{m})$ between the fibers. A number of round defects were found in the polyamide layer located at the aperture between the protein fibers in the bare ESC membrane (Figure S2). These defects account for the larger reverse ion flux as they enable free ion permeation. This free ion transport reduces the osmotic gradient across the active layer, which also reduces the osmotic water flux. Similarly, the inferior performance of the ESC-GO 1 membrane could be explained in terms of the surface morphology observed by FESEM. In the ESM-GO 1 membrane, there were deep wrinkles between each GO flake, and the polyamide layer was not deposited inside the wrinkles (Figure S1). Furthermore, large GO agglomerates were found on the surface of the ESC-GO 1 membrane (Figure S3), which may have hindered stable formation of the polyamide layer. It is also known that these GO aggregates cause the formation of physical defects in the polyamide layer [37]. Therefore, the low FO performance of ESM and ESMGO 1 is due to structural problems such as defect and partial absence in the polyamide layer. However, these defects were not found in the ESC-GO 0.1 and 0.5 membranes containing GO (Figure 6). The reduced defects could be explained by the morphology shown in Figure $4 \mathrm{~b}, \mathrm{c}$. In these membranes (ESM-GO 0.1 and 0.5), coated GO flakes filled the spaces between the protein fibers. The relatively smooth and hydrophilic surface formed by GO, instead of voids between the protein fibers, may lead to stable polyamide deposition. Moreover, GO contains a large amount of hydroxyl $(-\mathrm{OH})$ and carboxyl $(-\mathrm{COOH})$ groups that enhance the adhesion with polyamide and are known to be compatible with polyamide $[29,38,39]$.

Consequently, the parametric performance of $\mathrm{FO}$ membranes were characterized by the analytical method developed by Tiraferri et al. [26]. The coefficient of determination $\left(R^{2}\right)$ must be greater than 0.95 to be reliable, which is the yield value, but $R^{2}$ was smaller than the yield value in the case of ESC. The low $R^{2}$ value of the ESC, indicating that the determined value is not reliable, is expected due to poor and irregular ion exclusion [6], whereas the defective performance of ESC-GO 1 membrane was presented by poor parametric performance especially at dramatically high ion permeability, with reliable $R^{2}$ value. The parametric performance of the ESC-GO 0.1 and 0.5 membranes were reliably calculated in valid range, with $R^{2}$ higher than the yield values (Table 1 ). The characterized pure water permeability of the ESC-GO 0.1 and 0.5 membranes was 1.39 and $1.34 \mathrm{~L} \mathrm{~m}^{-2} \mathrm{~h}^{-1} \mathrm{bar}^{-1}$, respectively. The slightly lower pure water permeability of the latter is attributed to the higher content of GO at the interface of the polyamide layer. Instead, the ion permeability was lower for ESC-GO $0.5\left(3.10 \mathrm{~L} \mathrm{~m}^{-2} \mathrm{~h}^{-1}\right)$ compared to ESC-GO $0.1\left(3.57 \mathrm{~L} \mathrm{~m}^{-2} \mathrm{~h}^{-1}\right)$. In ESG-GO 0.1, 0.5 membrane, the flatter surface structure and presence of GO may have effected a lower ion permeability by enhancing the integrity of the polyamide layer. Finally, the calculated structural parameter of the ESC FO membranes was as low as $139 \mu \mathrm{m}$ (ESC- 
GO 0.1) and $125 \mu \mathrm{m}$ (ESC-GO 0.5). The slight difference between the structural parameter of the ESC-GO 0.1 and ESC-GO 0.5 membranes is attributed to the support layer hydrophilicity promoting complete wetting [40]. Although these values are higher than that of the electrospun polymeric support $(\sim 80 \mu \mathrm{m})[12,18]$, they are still considerably lower than those of membrane supports based on polymers and polymer-based nanocomposites $[8,41]$. These considerably low structural parameters are due to the ESM composed of crosslinked nano-microfibers constructing a less-tortuous diffusion path.

Table 1. Parametric performances of biocomposite membranes.

\begin{tabular}{|c|c|c|c|c|c|}
\hline Membrane & $\begin{array}{c}A \\
\left(\mathrm{~L} \mathrm{~m}^{-2} \mathrm{~h}^{-1} \mathrm{bar}^{-1}\right)\end{array}$ & $\begin{array}{c}B \\
\left(\mathrm{~L} \mathrm{~m}^{-2} \mathrm{~h}^{-1}\right)\end{array}$ & $\begin{array}{c}S \\
(\mu \mathrm{m})\end{array}$ & $\begin{array}{c}R^{2} \\
{\left[J_{w}\right]}\end{array}$ & $\begin{array}{l}R^{2} \\
{\left[J_{s}\right]}\end{array}$ \\
\hline ESC & 8.16 & 93.08 & 321 & 0.957 & 0.881 \\
\hline ESC-GO 0.1 & 1.39 & 3.57 & 138 & 0.981 & 0.972 \\
\hline ESC-GO 0.5 & 1.34 & 3.10 & 125 & 0.972 & 0.964 \\
\hline ESC-GO 1 & 7.18 & 355.15 & 243 & 0.997 & 0.997 \\
\hline
\end{tabular}

Table 2 shows the performance comparison with various FO membranes such as thin film nanocomposite (TFN), TFC, aquaporin and CA/CTA. Under similar conditions using $1 \mathrm{M} \mathrm{NaCl}$ DS in FO mode, biocomposite membranes exhibit higher water fluxes than TFC, aquaporin and CA/CTA-based membranes. The low structural parameter of biocomposite membrane, through short diffusion path between eggshell fibers in ESM, resulted in significantly higher FO performance as well as the feasibility of ESM as a material for the FO membrane.

Table 2. Comparison of FO performance with various types of membranes.

\begin{tabular}{|c|c|c|c|c|c|}
\hline Type of FO Membrane & $\begin{array}{l}\text { FO Water Flux } \\
\left(\mathrm{L} \mathrm{m}^{-2} \mathrm{~h}^{-1}\right)\end{array}$ & $\begin{array}{c}\text { Structural } \\
\text { Parameter } \\
(\mu \mathrm{m})\end{array}$ & $\begin{array}{l}\text { Draw } \\
\text { Solution }\end{array}$ & $\begin{array}{c}\text { Feed } \\
\text { Solution }\end{array}$ & References \\
\hline Biocomposite membrane & 27.8 & 125 & $1 \mathrm{M} \mathrm{NaCl}$ & DI Water & $\begin{array}{l}\text { This } \\
\text { work }\end{array}$ \\
\hline TFN & 46 & 80 & $1 \mathrm{M} \mathrm{NaCl}$ & DI Water & [12] \\
\hline TFN & 24.5 & 351 & $1 \mathrm{M} \mathrm{NaCl}$ & $\begin{array}{c}10 \mathrm{mM} \\
\mathrm{NaCl}\end{array}$ & [42] \\
\hline TFN & 19.6 & 646 & $1 \mathrm{M} \mathrm{NaCl}$ & $\begin{array}{c}20 \mathrm{mM} \\
\mathrm{NaCl}\end{array}$ & [43] \\
\hline TFC & 25 & 312 & $1 \mathrm{M} \mathrm{NaCl}$ & DI Water & [6] \\
\hline TFC & 20 & 238 & $1 \mathrm{M} \mathrm{NaCl}$ & DI Water & {$[44,45]$} \\
\hline Aquaporin & 8.8 & 569 & $1 \mathrm{M} \mathrm{NaCl}$ & DI Water & {$[45]$} \\
\hline Aquaporin & 23.1 & 420 & $1 \mathrm{M} \mathrm{NaCl}$ & DI Water & [46] \\
\hline CA/CTA & 5.1 & 54 & $1 \mathrm{M} \mathrm{NaCl}$ & DI Water & [47] \\
\hline $\mathrm{CA} / \mathrm{CTA}$ & 7.9 & 639 & $1 \mathrm{M} \mathrm{NaCl}$ & DI Water & {$[48]$} \\
\hline
\end{tabular}

\section{Conclusions}

In this study, we proposed a new approach for the design and fabrication of an FO membrane by exploiting the novel microstructure of ESM as a support layer. ESM was successfully employed to construct a biocomposite FO membrane by hybridization with a thin polyamide layer. Although bare ESM undesirably leads to poor integrity of the deposited polyamide layer, coating a small amount of GO on the ESM improved the integrity of the polyamide layer. Furthermore, the inherent fibrous structure of ESM, which is reported to provide a short diffusion length due to the superior porosity and interconnectivity, resulted in a low structural parameter of $138 \mu \mathrm{m}[12,49]$. The osmotic water flux of the biocomposite membrane reached $46.19 \mathrm{~L} \mathrm{~m}^{-2} \mathrm{~h}^{-1}$ with $2 \mathrm{M} \mathrm{NaCl} \mathrm{DS}$, because the structural parameter restricting the upper limit of the water flux was small [12,50]. The biocomposite membrane showed the potential of replacing synthetic polymer materials that occupy most of the weight of the FO membrane through the reuse of waste biomaterial. 
If additional scalable technology can be developed for large-area production, this approach provides green production fabricating a new type of membrane employing ESM, with significantly high FO performance as well as reduced chemical waste release.

Supplementary Materials: The following supporting information can be downloaded at: https: / / www.mdpi.com/article/10.3390/membranes12020166/s1, Figure S1: FESEM image of ESC and ESC-GO membranes at polyamide layer, Figure S2: Defects at polyamide layer in ESC membranes, Figure S3: Large agglomeration of GO in ESM-GO 1.

Author Contributions: Conceptualization, T.K. and K.K.; methodology, T.K., Y.L., S.P., J.K. and K.K.; validation, T.K., K.K. and J.K.; formal analysis, T.K., Y.L., S.P., J.K. and K.K.; writing-original draft preparation, T.K. and S.P.; writing-review and editing, T.K., J.K. and K.K.; supervision, K.K. All authors have read and agreed to the published version of the manuscript.

Funding: This work was supported by the National Research Foundation of Korea (NRF) grant funded by the Korea government (MSIT). (NRF-2020R1A2C4002557 and NRF-2019R1I1A3A0106345).

Data Availability Statement: Data is contained within the article and Supplementary Materials.

Conflicts of Interest: The authors declare no conflict of interest.

\section{References}

1. Zhao, S.F.; Zou, L.; Tang, C.Y.Y.; Mulcahy, D. Recent developments in forward osmosis: Opportunities and challenges. J. Membr. Sci. 2012, 396, 1-21. [CrossRef]

2. Chung, T.S.; Zhang, S.; Wang, K.Y.; Su, J.C.; Ling, M.M. Forward osmosis processes: Yesterday, today and tomorrow. Desalination 2012, 287, 78-81. [CrossRef]

3. Yang, Q.; Wang, K.Y.; Chung, T.S. A novel dual-layer forward osmosis membrane for protein enrichment and concentration. Sep. Purif. Technol. 2009, 69, 269-274. [CrossRef]

4. Wang, X.H.; Zhao, Y.X.; Yuan, B.; Wang, Z.W.; Li, X.F.; Ren, Y.P. Comparison of biofouling mechanisms between cellulose triacetate (CTA) and thin-film composite (TFC) polyamide forward osmosis membranes in osmotic membrane bioreactors. Bioresour. Technol. 2016, 202, 50-58. [CrossRef] [PubMed]

5. Idarraga-Mora, J.A.; Ladner, D.A.; Husson, S.M. Thin-film composite membranes on polyester woven mesh with variable opening size for pressure-retarded osmosis. J. Membr. Sci. 2018, 549, 251-259. [CrossRef]

6. Tiraferri, A.; Yip, N.Y.; Phillip, W.A.; Schiffman, J.D.; Elimelech, M. Relating performance of thin-film composite forward osmosis membranes to support layer formation and structure. J. Membr. Sci. 2011, 367, 340-352. [CrossRef]

7. Yip, N.Y.; Tiraferri, A.; Phillip, W.A.; Schiffman, J.D.; Elimelech, M. High Performance Thin-Film Composite Forward Osmosis Membrane. Environ. Sci. Technol. 2010, 44, 3812-3818. [CrossRef]

8. Emadzadeh, D.; Lau, W.J.; Matsuura, T.; Rahbari-Sisakht, M.; Ismail, A.F. A novel thin film composite forward osmosis membrane prepared from PSf- $\mathrm{TiO}_{2}$ nanocomposite substrate for water desalination. Chem. Eng. J. 2014, 237, 70-80. [CrossRef]

9. Ma, D.C.; Peh, S.B.; Han, G.; Chen, S.B. Thin-Film Nanocomposite (TFN) Membranes Incorporated with Super-Hydrophilic Metal- Organic Framework (MOF) UiO-66: Toward Enhancement of Water Flux and Salt Rejection. ACS Appl. Mater. Interfaces 2017, 9, 7523-7534. [CrossRef]

10. Idris, S.N.A.; Jullok, N.; Lau, W.J.; Ong, H.L.; Dong, C.D. Graphene Oxide Incorporated Polysulfone Substrate for Flat Sheet Thin Film Nanocomposite Pressure Retarded Osmosis Membrane. Membranes 2020, 10, 416. [CrossRef]

11. Pan, Y.H.; Zhao, Q.Y.; Gu, L.; Wu, Q.Y. Thin film nanocomposite membranes based on imologite nanotubes blended substrates for forward osmosis desalination. Desalination 2017, 421, 160-168. [CrossRef]

12. Song, X.X.; Liu, Z.Y.; Sun, D.R.D.L. Nano Gives the Answer: Breaking the Bottleneck of Internal Concentration Polarization with a Nanofiber Composite Forward Osmosis Membrane for a High Water Production Rate. Adv. Mater. 2011, $23,3256$. [CrossRef] [PubMed]

13. Puguan, J.M.C.; Kim, H.S.; Lee, K.J.; Kim, H. Low internal concentration polarization in forward osmosis membranes with hydrophilic crosslinked PVA nanofibers as porous support layer. Desalination 2014, 336, 24-31. [CrossRef]

14. Gonzales, R.R.; Park, M.J.; Tijing, L.; Han, D.S.; Phuntsho, S.; Shon, H.K. Modification of Nanofiber Support Layer for Thin Film Composite forward Osmosis Membranes via Layer-by-Layer Polyelectrolyte Deposition. Membranes 2018, 8, 70. [CrossRef]

15. Pathak, V.M.; Navneet. Review on the current status of polymer degradation: A microbial approach. Bioresour. Bioprocess. 2017, 4, 15. [CrossRef]

16. Xie, W.C.; Li, T.; Chen, C.; Wu, H.B.; Liang, S.M.; Chang, H.Q.; Liu, B.C.; Drioli, E.; Wang, Q.Y.; Crittenden, J.C. Using the Green Solvent Dimethyl Sulfoxide To Replace Traditional Solvents Partly and Fabricating PVC/PVC-g-PEGMA Blended Ultrafiltration Membranes with High Permeability and Rejection. Ind. Eng. Chem. Res. 2019, 58, 6413-6423. [CrossRef]

17. Tsai, W.T.; Yang, J.M.; Lai, C.W.; Cheng, Y.H.; Lin, C.C.; Yeh, C.W. Characterization and adsorption properties of eggshells and eggshell membrane. Bioresour. Technol. 2006, 97, 488-493. [CrossRef] [PubMed] 
18. Tian, M.; Wang, Y.N.; Wang, R. Synthesis and characterization of novel high-performance thin film nanocomposite (TFN) FO membranes with nanofibrous substrate reinforced by functionalized carbon nanotubes. Desalination 2015, 370, 79-86. [CrossRef]

19. Yi, F.; Guo, Z.X.; Zhang, L.X.; Yu, H.; Li, Q. Soluble eggshell membrane protein: Preparation, characterization and biocompatibility. Biomaterials 2004, 25, 4591-4599. [CrossRef]

20. Wang, W.D.; Chen, B.; Huang, Y.M.; Cao, J. Evaluation of eggshell membrane-based bio-adsorbent for solid-phase extraction of linear alkylbenzene sulfonates coupled with high-performance liquid chromatography. J. Chromatogr. A 2010, 1217, 5659-5664. [CrossRef]

21. Liu, J.K.; Wu, Q.S.; Ding, Y.P.; Wang, S.Y. Biomimetic synthesis of BaSO4 nanotubes using eggshell membrane as template. J. Mater. Res. 2004, 19, 2803-2806. [CrossRef]

22. Zhang, D.; Zhao, H.; Fan, Z.; Li, M.; Du, P.; Liu, C.; Li, Y.; Li, H.; Cao, H. A highly sensitive and selective hydrogen peroxide biosensor based on gold nanoparticles and three-dimensional porous carbonized chicken eggshell membrane. PLOS ONE 2015, 10, e0130156. [CrossRef] [PubMed]

23. Park, S.; Choi, K.S.; Lee, D.; Kim, D.; Lim, K.T.; Lee, K.H.; Seonwoo, H.; Kim, J. Eggshell membrane: Review and impact on engineering. Biosyst. Eng. 2016, 151, 446-463. [CrossRef]

24. Hummers Jr, W.S.; Offeman, R.E. Preparation of graphitic oxide. J. Am. Chem. Soc. 1958, 80, 1339. [CrossRef]

25. Ghosh, A.K.; Jeong, B.H.; Huang, X.F.; Hoek, E.M.V. Impacts of reaction and curing conditions on polyamide composite reverse osmosis membrane properties. J. Membr. Sci. 2008, 311, 34-45. [CrossRef]

26. Tiraferri, A.; Yip, N.Y.; Straub, A.P.; Castrillon, S.R.V.; Elimelech, M. A method for the simultaneous determination of transport and structural parameters of forward osmosis membranes. J. Membr. Sci. 2013, 444, 523-538. [CrossRef]

27. Vitagliano, V.; Lyons, P.A. Diffusion coefficients for aqueous solutions of sodium chloride and barium chloride. J. Am. Chem. Soc. 1956, 78, 1549-1552. [CrossRef]

28. Li, Y.F.; Su, Y.L.; Li, J.Y.; Zhao, X.T.; Zhang, R.N.; Fan, X.C.; Zhu, J.N.; Ma, Y.Y.; Liu, Y.; Jiang, Z.Y. Preparation of thin film composite nanofiltration membrane with improved structural stability through the mediation of polydopamine. J. Membr. Sci. 2015, 476, 10-19. [CrossRef]

29. Park, S.J.; Choi, W.; Nam, S.E.; Hong, S.; Lee, J.S.; Lee, J.H. Fabrication of polyamide thin film composite reverse osmosis membranes via support-free interfacial polymerization. J. Membr. Sci. 2017, 526, 52-59. [CrossRef]

30. Wang, S.F.; Yu, Y.; Wu, Q.Y. High-performance Thin Film Composite forward Osmosis Membrane with Polydopamine/Polyethylen eimine (PDA/PEI) Co-deposition Interlayer. Acta Polym. Sin. 2020, 51, 385-392. [CrossRef]

31. Ribeiro-Soares, J.; Oliveros, M.E.; Garin, C.; David, M.V.; Martins, L.G.P.; Almeida, C.A.; Martins-Ferreira, E.H.; Takai, K.; Enoki, T.; Magalhaes-Paniago, R.; et al. Structural analysis of polycrystalline graphene systems by Raman spectroscopy. Carbon 2015, 95, 646-652. [CrossRef]

32. Stankovich, S.; Dikin, D.A.; Piner, R.D.; Kohlhaas, K.A.; Kleinhammes, A.; Jia, Y.; Wu, Y.; Nguyen, S.T.; Ruoff, R.S. Synthesis of graphene-based nanosheets via chemical reduction of exfoliated graphite oxide. Carbon 2007, 45, 1558-1565. [CrossRef]

33. Bano, S.; Mahmood, A.; Kim, S.J.; Lee, K.H. Graphene oxide modified polyamide nanofiltration membrane with improved flux and antifouling properties. J. Mater. Chem. A 2015, 3, 2065-2071. [CrossRef]

34. Nguyen, T.P.N.; Yun, E.T.; Kim, I.C.; Kwon, Y.N. Preparation of cellulose triacetate/cellulose acetate (CTA/CA)-based membranes for forward osmosis. J. Membr. Sci. 2013, 433, 49-59. [CrossRef]

35. Zhang, S.; Wang, K.Y.; Chung, T.S.; Chen, H.M.; Jean, Y.C.; Amy, G. Well-constructed cellulose acetate membranes for forward osmosis: Minimized internal concentration polarization with an ultra-thin selective layer. J. Membr. Sci. 2010, 360, 522-535. [CrossRef]

36. Liong, J.W.W.; Frank, J.F.; Bailey, S. Visualization of eggshell membranes and their interaction with Salmonella enteritidis using confocal scanning laser microscopy. J. Food Prot. 1997, 60, 1022-1028. [CrossRef] [PubMed]

37. Lim, S.; Park, K.H.; Tran, V.H.; Akther, N.; Phuntsho, S.; Choi, J.Y.; Shon, H.K. Size -controlled graphene oxide for highly permeable and fouling -resistant outer -selective hollow fiber thin-film composite membranes for forward osmosis. J. Membr. Sci. 2020, 609, 118171. [CrossRef]

38. Faria, A.F.; Liu, C.; Xie, M.; Perreault, F.; Nghiem, L.D.; Ma, J.; Elimelech, M. Thin-film composite forward osmosis membranes functionalized with graphene oxide-silver nanocomposites for biofouling control. J. Membr. Sci. 2017, 525, 146-156. [CrossRef]

39. Xia, S.; Yao, L.; Zhao, Y.; Li, N.; Zheng, Y. Preparation of graphene oxide modified polyamide thin film composite membranes with improved hydrophilicity for natural organic matter removal. Chem. Eng. J. 2015, 280, 720-727. [CrossRef]

40. Arena, J.T.; McCloskey, B.; Freeman, B.D.; McCutcheon, J.R. Surface modification of thin film composite membrane support layers with polydopamine: Enabling use of reverse osmosis membranes in pressure retarded osmosis. J. Membr. Sci. 2011, 375 , 55-62. [CrossRef]

41. Ghanbari, M.; Emadzadeh, D.; Lau, W.J.; Riazi, H.; Almasi, D.; Ismail, A.F. Minimizing structural parameter of thin film composite forward osmosis membranes using polysulfone/halloysite nanotubes as membrane substrates. Desalination 2016, 377, 152-162. [CrossRef]

42. Ma, D.C.; Han, G.; Peh, S.B.; Chen, S.B. Water-Stable Metal-Organic Framework UiO-66 for Performance Enhancement of Forward Osmosis Membranes. Ind. Eng. Chem. Res. 2017, 56, 12773-12782. [CrossRef] 
43. Zhang, X.; Zheng, J.H.; Xu, L.S.; Yin, M.; Zhang, G.L.; Zhao, W.Q.; Zhang, Z.Y.; Shen, C.; Meng, Q. Novel Thin Film Nanocomposite Forward Osmosis Membranes Prepared by Organic Phase Controlled Interfacial Polymerization with Functional Multi-Walled Carbon Nanotubes. Membranes 2021, 11, 476. [CrossRef] [PubMed]

44. Lim, S.; Park, M.J.; Phuntsho, S.; Tijing, L.D.; Nisola, G.M.; Shim, W.G.; Chung, W.J.; Shon, H.K. Dual-layered nanocomposite substrate membrane based on polysulfone/graphene oxide for mitigating internal concentration polarization in forward osmosis. Polymer 2017, 110, 36-48. [CrossRef]

45. Xia, L.L.; Andersen, M.F.; Helix-Nielsen, C.; McCutcheon, J.R. Novel Commercial Aquaporin Flat-Sheet Membrane for Forward Osmosis. Ind. Eng. Chem. Res. 2017, 56, 11919-11925. [CrossRef]

46. Chun, Y.P.; Qing, L.; Sun, G.F.; Bilad, M.R.; Fane, A.G.; Chong, T.H. Prototype aquaporin-based forward osmosis membrane: Filtration properties and fouling resistance. Desalination 2018, 445, 75-84. [CrossRef]

47. Qin, D.T.; Liu, Z.Y.; Bai, H.W.; Song, X.X.; Li, Z.T.; Sun, D.D. Fine-tuning selective layer architecture of hydrogel membrane towards high separation performances for engineered osmosis. J. Membr. Sci. 2019, 592, 117370. [CrossRef]

48. Shibuya, M.; Yasukawa, M.; Takahashi, T.; Miyoshi, T.; Higa, M.; Matsuyama, H. Effect of operating conditions on osmotic-driven membrane performances of cellulose triacetate forward osmosis hollow fiber membrane. Desalination 2015, 362, 34-42. [CrossRef]

49. Bui, N.N.; Lind, M.L.; Hoek, E.M.V.; McCutcheon, J.R. Electrospun nanofiber supported thin film composite membranes for engineered osmosis. J. Membr. Sci. 2011, 385, 10-19. [CrossRef]

50. McCutcheon, J.R.; Elimelech, M. Influence of concentrative and dilutive internal concentration polarization on flux behavior in forward osmosis. J. Membr. Sci. 2006, 284, 237-247. [CrossRef] 